\title{
Nitrogen Loss through Anaerobic Ammonium Oxidation Coupled to Iron Reduction from Paddy Soils in a Chronosequence
}

\author{
Long-Jun Ding, ${ }^{\dagger, \ddagger}$ Xin-Li An, ${ }^{\S}$ Shun Li, ${ }^{\ddagger}, \S$ Gan-Lin Zhang, ${ }^{\prime \prime}$ and Yong-Guan Zhu ${ }^{*},, \S$ \\ ${ }^{\dagger}$ State Key Laboratory of Urban and Regional Ecology, Research Center for Eco-Environmental Sciences, Chinese Academy of \\ Sciences, Shuangqing Road, No. 18, Haidian District, Beijing 100085, People's Republic of China \\ ${ }^{\ddagger}$ University of Chinese Academy of Sciences, Yuquan Road, No. 19A, Shijingshan District, Beijing 100049, People’s Republic of China \\ ${ }^{\S}$ Key Laboratory of Urban Environment and Health, Institute of Urban Environment, Chinese Academy of Sciences, Jimei Road, No. \\ 1799, Jimei District, Xiamen 361021, People's Republic of China \\ "State Key Laboratory of Soil and Sustainable Agriculture, Institute of Soil Science, Chinese Academy of Sciences, East Beijing Road, \\ No. 71, Xuanwu District, Nanjing 210008, People's Republic of China
}

\section{Supporting Information}

ABSTRACT: Anaerobic ammonium oxidation coupled to iron(III) reduction (termed Feammox) with dinitrogen, nitrite, or nitrate as the end-product is a recently discovered process of nitrogen cycling. However, Feammox has not been described in paddy soils, which are rich in iron(III) oxides and subjected to intensive nitrogen fertilization. Here, evidence for Feammox in a paddy soil chronosequence with a gradient of microbially reducible iron(III) levels was obtained in Southern China using ${ }^{15} \mathrm{~N}$-labeled ammonium-based isotopic tracing and acetylene inhibition techniques. Our study demonstrated the occurrence of Feammox in the chronosequence, and direct dinitrogen production was shown to be the dominant Feammox pathway. Within the chronosequence, three paddy soils with higher microbially reducible iron(III) levels had higher Feammox rates (ranged from 0.17 to $0.59 \mathrm{mg} \mathrm{N} \mathrm{kg}^{-1} \mathrm{~d}^{-1}$ ) compared to an uncultivated soil $\left(0.04 \mathrm{mg} \mathrm{N} \mathrm{kg}^{-1} \mathrm{~d}^{-1}\right)$. It is estimated that a

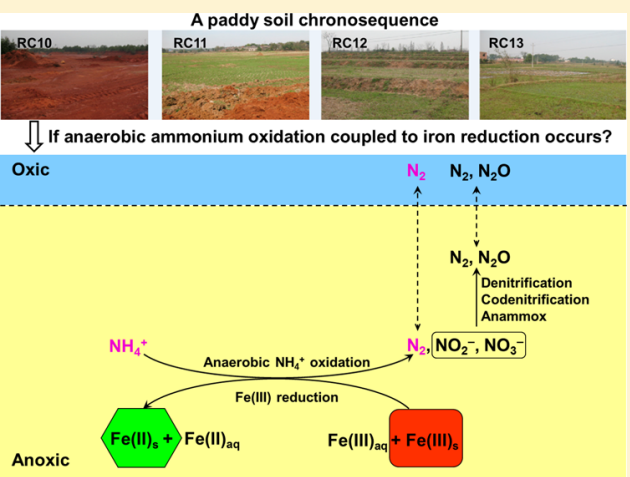
loss of $7.8-61 \mathrm{~kg} \mathrm{~N} \mathrm{ha}^{-1}$ year $^{-1}$ is associated with Feammox in the examined paddy soils. Overall, we discover that rice cultivation could enrich microbially reducible iron(III), accelerate Feammox reaction and thus fuel nitrogen loss from soils, and suggest that Feammox could be a potentially important pathway for nitrogen loss in paddy soils.

\section{INTRODUCTION}

Rice is a global staple food which is grown on approximately 155 million hectare (ha) of the Earth's surface and feeds more than half of the world's population. ${ }^{1}$ Nitrogen $(\mathrm{N})$ fertilizers (usually as urea and ammonia) have been applied intensively in paddy soils to obtain high yields over the last decades, especially in China, which is one of the major rice producers in the world and has become the largest producer and consumer of $\mathrm{N}$ fertilizers so far, accounting for one-third of world fertilizer production in $2010 .^{2}$ The amounts of $\mathrm{N}$ fertilizers applied to paddy soils are likely to further increase to feed growing populations. However, the excessive use of $\mathrm{N}$ fertilizers has not only decreased $\mathrm{N}$-utilization efficiency by crops, but also increased $\mathrm{N}$ loss to the environment, leading to pollution in atmosphere and water systems. ${ }^{3,4}$ Therefore, concerns regarding $\mathrm{N}$ pollution of the environment have been raised for decades, and numerous studies have been focused on pathways of $\mathrm{N}$ cycling in paddy soils. ${ }^{1,4-7}$

Traditionally, three distinct microbial processes, denitrification, codenitrification, and anaerobic ammonium $\left(\mathrm{NH}_{4}^{+}\right)$ oxidation (anammox), are usually involved in the $\mathrm{N}$ loss from terrestrial ecosystems via the generation of nitrous oxide $\left(\mathrm{N}_{2} \mathrm{O}\right)$ or dinitrogen gas $\left(\mathrm{N}_{2}\right) \cdot{ }^{8-10}$ In addition to these processes, it has recently been discovered that anaerobic $\mathrm{NH}_{4}^{+}$oxidation could be coupled to ferric iron (Fe(III)) reduction (termed Feammox) with either $\mathrm{N}_{2}$ (eq 1), ${ }^{11}$ nitrite $\left(\mathrm{NO}_{2}{ }^{-}\right)$(eq 2), ${ }^{11-14}$ or nitrate $\left(\mathrm{NO}_{3}^{-}\right)(\text {eq } 3)^{11}$ as the end-product in several environments. For example, anaerobic oxidation of $\mathrm{NH}_{4}^{+}$to $\mathrm{NO}_{2}{ }^{-}$has been detected under iron-reducing conditions in wetland soils. ${ }^{12,14}$ Moreover, Yang et al. ${ }^{11}$ found the evidence of $\mathrm{N}_{2}, \mathrm{NO}_{2}{ }^{-}$, or $\mathrm{NO}_{3}{ }^{-}$production via Feammox in tropical forest soils. These new findings implicate alternative pathways of $\mathrm{N}$ loss from soils. However, few studies have focused on soil indigenous microbially reducible iron(III) utilization as the sole electron acceptor during the Feammox process, and to date there has been no report on the occurrence of Feammox in paddy soils. Whether Feammox could occur and make a contribution to total $\mathrm{N}$ loss in paddy soils is unknown at the moment. Considering that paddy soils are one of the most

Received: June 27, 2014

Revised: August 23, 2014

Accepted: August 26, 2014

Published: August 26, 2014 
important $\mathrm{N}$ sinks in terrestrial ecosystems, ${ }^{15} \mathrm{Fe}$ (III) is by far the most abundant oxidant in paddy soils, and the periodic alternation between oxic and anoxic conditions in paddy soils can promote Fe redox reactions, we hypothesize that paddy soils have the potential to support Feammox.

$$
\begin{aligned}
& 3 \mathrm{Fe}(\mathrm{OH})_{3}+5 \mathrm{H}^{+}+\mathrm{NH}_{4}^{+} \rightarrow 3 \mathrm{Fe}^{2+}+9 \mathrm{H}_{2} \mathrm{O}+0.5 \mathrm{~N}_{2} \\
& 6 \mathrm{Fe}(\mathrm{OH})_{3}+10 \mathrm{H}^{+}+\mathrm{NH}_{4}^{+} \rightarrow 6 \mathrm{Fe}^{2+}+16 \mathrm{H}_{2} \mathrm{O}+\mathrm{NO}_{2}^{-}
\end{aligned}
$$

$$
8 \mathrm{Fe}(\mathrm{OH})_{3}+14 \mathrm{H}^{+}+\mathrm{NH}_{4}^{+} \rightarrow 8 \mathrm{Fe}^{2+}+21 \mathrm{H}_{2} \mathrm{O}+\mathrm{NO}_{3}^{-}
$$

The primary objective of this study was thus to quantitatively determine if Feammox occurs in paddy soils using a chronosequence in Southern China. The relative contribution of the Feammox pathways was also identified by combining ${ }^{15} \mathrm{~N}$-labeled $\mathrm{NH}_{4}^{+}\left({ }^{15} \mathrm{NH}_{4}^{+}\right)$-based isotopic tracing and acetylene $\left(\mathrm{C}_{2} \mathrm{H}_{2}\right)$ inhibition techniques.

\section{MATERIALS AND METHODS}

Site Description and Soil Sampling. Paddy terraces in the hilly regions of Southern China, with increasing age of cultivation from the top to the bottom of the slopes, provide soil chronosequences. A paddy soil chronosequence developed from Quaternary red clays (RC) was selected for our study. The chronosequence is located in Jinxian, central Jiangxi Province of China (between $28^{\circ} 10^{\prime}-28^{\circ} 45^{\prime} \mathrm{N}, 116^{\circ} 1^{\prime}-$ $116^{\circ} 34^{\prime} \mathrm{E}$ ), which represents a typical hilly region for rice cultivation in subtropical Southern China. Within the chronosequence, four representative soils were selected for sampling. Three cultivated soils at the top, middle, and bottom of the slope with increasing age of rice cultivation were named as RC11 (100 years), RC12 (100-300 years), and RC13 (300 years) soils, respectively. An uncultivated soil (time zero) at the highest slope position were named as RC10 soil. The sampling positions and image of the chronosequence are shown in Supporting Information (SI) Figure S1. Details of the sampling site and chronosequence have been described in a previous study. ${ }^{16}$ Surface soil samples $(0-10 \mathrm{~cm}$ depth) were collected after rice harvest when fields had been drained for about 7 up to 10 days. Each soil sample was partitioned into two subsamples: one was air-dried, passed through a $2.0 \mathrm{~mm}$ sieve for soil chemical properties analyses, and the second was used for isotope tracer incubations. The analytical methods of soil chemical properties are given in the SI.

Isotope Tracer Incubations. The entire incubation experiment was performed in an ultrahigh purity helium (He)-filled anaerobic glovebox (Shel Lab Bactron IV, U.S.A.) equipped with a solution of resazurin as the redox indicator. In our study, the resazurin solution remained colorless throughout the experiment indicating the anoxic conditions in the glovebox. Prior to incubation, soil slurries were prepared by adding sterile anoxic deionized water to the soils (oven-dry equivalent) at a ratio of $3: 1(\mathrm{v} / \mathrm{w})$, and preincubated anoxically in the dark at $25{ }^{\circ} \mathrm{C}$ for 2 days to remove indigenous oxygen $\left(\mathrm{O}_{2}\right)$ and $\mathrm{NO}_{x}^{-}$(i.e., $\mathrm{NO}_{2}^{-}$and $\mathrm{NO}_{3}^{-}$) (see SI). After the preincubation, indigenous microbially reducible $\mathrm{Fe}$ (III) in all soil slurries remained almost unreduced (data not shown). Aliquots $(6 \mathrm{~g})$ of the homogenized slurries were transferred into $60 \mathrm{~mL}$ serum vials, which were then sealed with butyl rubber septa and crimped with aluminum caps. The headspace of soil slurries was flushed with ultrahigh purity He. Three treatments ( $n=6$ per treatment) were established: (i) control treatment with sterile anoxic deionized water instead of ${ }^{15} \mathrm{NH}_{4} \mathrm{Cl}$; (ii) ${ }^{15} \mathrm{NH}_{4} \mathrm{Cl}$ addition $\left({ }^{15} \mathrm{~N}\right.$ at $99 \%$, Cambridge Isotope Laboratories, Andover, U.S.A.; ${ }^{15} \mathrm{NH}_{4}^{+}$); and (iii) ${ }^{15} \mathrm{NH}_{4} \mathrm{Cl}$ and $\mathrm{C}_{2} \mathrm{H}_{2}$ addition $\left({ }^{15} \mathrm{NH}_{4}^{+}+\mathrm{C}_{2} \mathrm{H}_{2}\right)$. The final concentration of ${ }^{15} \mathrm{NH}_{4} \mathrm{Cl}$ was $90 \mathrm{mg} \mathrm{N} \mathrm{kg}{ }^{-1}$ soil dry weight, by injecting $0.5 \mathrm{~mL}$ of ultrahigh purity He-purged stock solution. The amount of ${ }^{15} \mathrm{NH}_{4}^{+}$amended was chosen based on the actual amount of chemical $\mathrm{N}$ fertilizer usually applied to paddy soils in China (about $200 \mathrm{~kg} \mathrm{~N} \mathrm{ha}^{-1}$ year $^{-1}$ ). ${ }^{4,17}$ For the $\mathrm{C}_{2} \mathrm{H}_{2}$ treatment, $23 \mathrm{~mL}$ headspace gas in each vial was removed and replaced with $23 \mathrm{~mL} \mathrm{C}_{2} \mathrm{H}_{2}$ to reach $30 \%(\mathrm{v} / \mathrm{v}) \mathrm{C}_{2} \mathrm{H}_{2}$ in the headspace. All vials were shaken vigorously to homogenize the treatment solutions and dissolve the $\mathrm{C}_{2} \mathrm{H}_{2}$.

The destructive sampling was carried out at 1 day intervals up to 6 days from each vial. Before sampling, each vial was shaken vigorously to equilibrate the gas between dissolved and gaseous phases. For analysis of ${ }^{15} \mathrm{~N}-\mathrm{N}_{2}$ and ${ }^{15} \mathrm{~N}-\mathrm{N}_{2} \mathrm{O}, 12 \mathrm{~mL}$ gas samples were immediately collected by gastight syringes and then injected into $12 \mathrm{~mL}$ pre-evacuated glass vials (Exetainer, Labco, U.K.). To prevent atmospheric contamination, these sampling processes were conducted in the Hefilled anaerobic glovebox. The ${ }^{15} \mathrm{~N}$ enrichment in $\mathrm{N}_{2}$ was determined by isotope ratio mass spectrometry (IRMS, Thermo Finnigan Delta V Advantage, Bremen, Germany) coupled with GasBench II, and the ${ }^{15} \mathrm{~N}$ enrichment in $\mathrm{N}_{2} \mathrm{O}$ was determined by IRMS coupled with a preconcentration unit. ${ }^{18}$ Headspace $\mathrm{N}_{2}$ and $\mathrm{N}_{2} \mathrm{O}$ concentrations were directly measured using a robotized sampling and analyzing system, ${ }^{19}$ which was composed of an autosampler with a peristaltic pump, a thermostatic water bath and an Agilent 7890 gas chromatography (Santa Clara, CA, U.S.A.). ${ }^{15} \mathrm{~N}_{2}$ concentration was calculated as the product of $\mathrm{N}_{2}$ concentration and ${ }^{15} \mathrm{~N}-\mathrm{N}_{2}$ atom $\%$ excess above its natural abundance. ${ }^{20}{ }^{15} \mathrm{~N}_{2} \mathrm{O}$ concentration was also calculated as the product of $\mathrm{N}_{2} \mathrm{O}$ concentration and ${ }^{15} \mathrm{~N}-\mathrm{N}_{2} \mathrm{O}$ atom\% excess above its natural abundance. ${ }^{21}{ }^{15} \mathrm{~N}_{2}$ and ${ }^{15} \mathrm{~N}_{2} \mathrm{O}$ production rates were calculated from the linear change in ${ }^{15} \mathrm{~N}_{2}$ and ${ }^{15} \mathrm{~N}_{2} \mathrm{O}$ concentrations in the vial headspace between two given time points. Potential Feammox rates were conservatively estimated from the difference in vial headspace ${ }^{30} \mathrm{~N}_{2}$ production alone with and without ${ }^{15} \mathrm{NH}_{4}^{+}$addition.

After the gas sampling, the slurries were subsampled for analysis of $\mathrm{HCl}$-extractable $\mathrm{Fe}(\mathrm{II})$ and total extractable $\mathrm{Fe}$ using the procedure slightly modified from Lovley et al. ${ }^{22}$ Briefly, 1.0 $\mathrm{g}$ of soil slurry sample was extracted with $5 \mathrm{~mL} 0.5 \mathrm{M} \mathrm{HCl}$ for 2 $\mathrm{h}$ at room temperature, and extracted $\mathrm{Fe}$ (II) was determined using the ferrozine method. Total extractable $\mathrm{Fe}$ in the slurry sample was analyzed by the same procedure with the exception that the extractant was $5 \mathrm{~mL} 0.25 \mathrm{M}$ hydroxylamine hydrochloride in $0.25 \mathrm{M} \mathrm{HCl}$. The amount of microbially reducible $\mathrm{Fe}$ (III) (considered as hydroxylamine-reducible $\mathrm{Fe}(\mathrm{III})$ ) was calculated as the difference between total extractable $\mathrm{Fe}$ and $\mathrm{Fe}(\mathrm{II}){ }^{22}$ All extractions were conducted in the anaerobic glovebox. $\mathrm{Fe}$ (III) reduction rates were calculated from the linear change in $\mathrm{Fe}$ (II) concentrations between two given time points.

Statistical Analyses. SPSS (version 16.0; SPSS Inc., Chicago, IL, U.S.A.) software was used to perform standard statistical tests, including analysis of variance (ANOVA) and Pearson correlation analysis. We performed two-tailed student's $t$ tests to compare ${ }^{15} \mathrm{~N}_{2}$ or ${ }^{15} \mathrm{~N}_{2} \mathrm{O}$ production rates, and $\mathrm{Fe}(\mathrm{II})$ 
Table 1. Chemical Characteristics of the Paddy Soil Chronosequence ${ }^{a}$

\begin{tabular}{|c|c|c|c|c|c|c|c|c|}
\hline soil & $\mathrm{pH}$ & $\begin{array}{l}\text { microbially reducible } \mathrm{Fe}(\mathrm{III}) \\
\qquad\left(\mathrm{g} \mathrm{kg}^{-1}\right)\end{array}$ & $\begin{array}{l}\text { total Fe } \\
\left(\mathrm{g} \mathrm{kg}^{-1}\right)\end{array}$ & $\begin{array}{l}\mathrm{TOC}^{b} \\
\left(\mathrm{~g} \mathrm{~kg}^{-1}\right)\end{array}$ & $\mathrm{TN}^{b}\left(\mathrm{~g} \mathrm{~kg}^{-1}\right)$ & $\begin{array}{l}\mathrm{NH}_{4}^{+}-\mathrm{N} \\
\left(\mathrm{mg} \mathrm{kg}^{-1}\right)\end{array}$ & $\begin{array}{l}\mathrm{NO}_{x}-\mathrm{N}^{b} \\
\left(\mathrm{mg} \mathrm{kg}^{-1}\right)\end{array}$ & $\begin{array}{c}\mathrm{DOC}^{b} \\
\left(\mathrm{mg} \mathrm{kg}^{-1}\right)\end{array}$ \\
\hline $\mathrm{RC} 10$ & $4.7 \pm 0.01 \mathrm{D}^{c}$ & $0.54 \pm 0.03 \mathrm{D}$ & $65 \pm 2.2 \mathrm{~A}$ & $8.7 \pm 0.38 \mathrm{D}$ & $0.80 \pm 0.03 \mathrm{D}$ & $7.0 \pm 0.21 \mathrm{D}$ & $1.2 \pm 0.06 \mathrm{D}$ & $72 \pm 3.3 \mathrm{D}$ \\
\hline $\mathrm{RC} 11$ & $4.9 \pm 0.01 \mathrm{C}$ & $1.6 \pm 0.06 \mathrm{C}$ & $26 \pm 1.2 \mathrm{D}$ & $19 \pm 0.41 \mathrm{~B}$ & $1.9 \pm 0.06 \mathrm{~B}$ & $15 \pm 0.40 \mathrm{~B}$ & $2.1 \pm 0.07 \mathrm{C}$ & $165 \pm 6.9 \mathrm{~B}$ \\
\hline $\mathrm{RC} 12$ & $5.3 \pm 0.01 \mathrm{~B}$ & $4.5 \pm 0.16 \mathrm{~A}$ & $47 \pm 1.5 \mathrm{~B}$ & $16 \pm 0.33 \mathrm{C}$ & $1.4 \pm 0.04 \mathrm{C}$ & $10 \pm 0.31 \mathrm{C}$ & $2.9 \pm 0.09 \mathrm{~A}$ & $126 \pm 5.7 \mathrm{C}$ \\
\hline $\mathrm{RC} 13$ & $5.7 \pm 0.02 \mathrm{~A}$ & $3.2 \pm 0.11 \mathrm{~B}$ & $35 \pm 1.3 \mathrm{C}$ & $24 \pm 0.73 \mathrm{~A}$ & $2.2 \pm 0.08 \mathrm{~A}$ & $21 \pm 0.65 \mathrm{~A}$ & $2.4 \pm 0.09 \mathrm{~B}$ & $218 \pm 9.4 \mathrm{~A}$ \\
\hline
\end{tabular}

${ }^{a_{T}}$ The paddy soil chronosequence contains an uncultivated soil (RC10, time zero) and three cultivated paddy soils at the top (RC11, 100 years), middle (RC12, 100-300 years), and bottom (RC13, 300 years) of the slope with increasing cultivation age. ${ }^{b}$ TOC: Total organic carbon; TN: Total nitrogen; $\mathrm{NO}_{x}{ }^{-}: \mathrm{NO}_{2}{ }^{-}$and $\mathrm{NO}_{3}{ }^{-}$; DOC: Dissolved organic carbon. ${ }^{c}$ Mean \pm standard error $(n=6)$. The different capital letters within the same column indicate statistically significant $(P<0.05)$ differences among different soils.
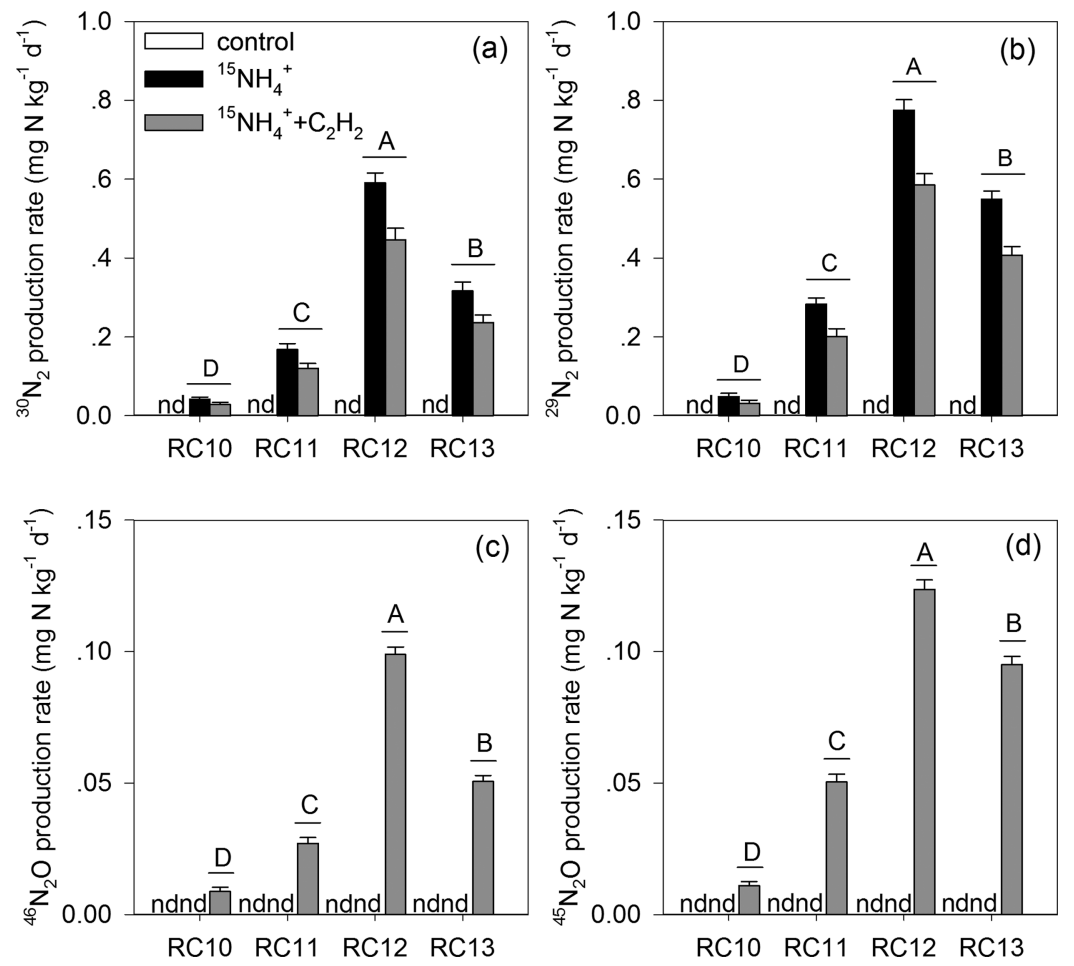

Figure 1. Mean headspace ${ }^{15} \mathrm{~N}_{2}$ and ${ }^{15} \mathrm{~N}_{2} \mathrm{O}$ production rates for the examined paddy soil chronosequence. (a-d), mean headspace ${ }^{30} \mathrm{~N}_{2}(\mathrm{a})$, ${ }^{29} \mathrm{~N}_{2}$ (b), ${ }^{46} \mathrm{~N}_{2} \mathrm{O}$ (c), and ${ }^{45} \mathrm{~N}_{2} \mathrm{O}$ (d) production rates in the control, ${ }^{15} \mathrm{NH}_{4}{ }^{+}$and ${ }^{15} \mathrm{NH}_{4}{ }^{+}+\mathrm{C}_{2} \mathrm{H}_{2}$ treatments. The different capital letters above the horizontal line denote statistically significant $(P<0.05)$ differences among different soils regardless of the treatments, using two-way analysis of variance. Error bars represent standard errors $(n=6)$. nd = not detectable within a detection limit of $0.008 \mathrm{mg}^{15} \mathrm{~N} \mathrm{~kg}^{-1} \mathrm{~d}^{-1}$.

production between treatments with ${ }^{15} \mathrm{NH}_{4}^{+}$addition $\left({ }^{15} \mathrm{NH}_{4}^{+}\right.$ and ${ }^{15} \mathrm{NH}_{4}^{+}+\mathrm{C}_{2} \mathrm{H}_{2}$ ) and control to determine whether significant $\mathrm{NH}_{4}^{+}$oxidation and promotion of $\mathrm{Fe}(\mathrm{II})$ production occurred in the presence of ${ }^{15} \mathrm{NH}_{4}^{+}$. We also compared ${ }^{15} \mathrm{~N}_{2}$ or ${ }^{15} \mathrm{~N}_{2} \mathrm{O}$ production rates between ${ }^{15} \mathrm{NH}_{4}^{+}$and ${ }^{15} \mathrm{NH}_{4}^{+}+\mathrm{C}_{2} \mathrm{H}_{2}$ treatments in each soil using two-tailed student's $t$ tests. Moreover, we compared ${ }^{15} \mathrm{~N}_{2}$ or ${ }^{15} \mathrm{~N}_{2} \mathrm{O}$ production rates among different soils regardless of the treatments, using twoway analysis of variance. Mean values are shown in the text followed by standard errors $( \pm S E)$. Statistical significance was denoted at $P<0.05$ unless otherwise noted.

\section{RESULTS}

Chemical Characteristics of the Paddy Soil Chronosequence. For the examined chronosequence, which was composed of an uncultivated soil (RC10 soil) and three cultivated paddy soils at the top (RC11 soil), middle (RC12 soil), and bottom (RC13 soil) of a slope with increasing cultivation age, the measurements of microbially reducible $\mathrm{Fe}(\mathrm{III})$, total $\mathrm{Fe}$, and other chemical properties including $\mathrm{pH}$, total organic carbon (TOC), total nitrogen (TN), $\mathrm{NH}_{4}^{+}, \mathrm{NO}_{x}^{-}$ (i.e., $\mathrm{NO}_{2}^{-}$and $\mathrm{NO}_{3}{ }^{-}$), and dissolved organic carbon (DOC) are shown in Table 1. A gradient of microbially reducible $\mathrm{Fe}$ (III) levels was an important characteristic of the chronosequence, varying considerably from the lowest $(0.54$ $\left.\pm 0.03 \mathrm{~g} \mathrm{~kg}^{-1}\right)$ in the RC10 soil to the highest $(4.5 \pm 0.16 \mathrm{~g}$ $\mathrm{kg}^{-1}$ ) in the RC12 soil. In contrast, the concentration of total $\mathrm{Fe}$ in the uncultivated soil (i.e., RC10 soil) was much higher than in all paddy soils (i.e., RC11, RC12, and RC13 soils). These indicated that long-term rice cultivation could enrich amorphous $\mathrm{Fe}$ (III) oxides while decreasing total iron. Furthermore, the $\mathrm{pH}$ value and concentrations of TOC, TN, $\mathrm{NH}_{4}^{+}, \mathrm{NO}_{x}^{-}$, and DOC in all paddy soils were significantly $(P$ $<0.05$ ) higher than that in the uncultivated soil, indicating that long-term rice cultivation could modify the soil $\mathrm{pH}$ to neutral values and elevate soil nutrient levels.

${ }^{15} \mathrm{~N}_{2}$ and ${ }^{15} \mathrm{~N}_{2} \mathrm{O}$ Production from Anoxic Incubations. For all soils, significant amount of ${ }^{30} \mathrm{~N}_{2}\left({ }^{15} \mathrm{~N}^{15} \mathrm{~N}\right)$ was detected in treatments with ${ }^{15} \mathrm{NH}_{4}^{+}$, and ${ }^{15} \mathrm{NH}_{4}^{+}$and $\mathrm{C}_{2} \mathrm{H}_{2}\left({ }^{15} \mathrm{NH}_{4}{ }^{+}+\right.$ $\mathrm{C}_{2} \mathrm{H}_{2}$ ), but was not detectable in the control (without ${ }^{15} \mathrm{NH}_{4}^{+}$) 
after 6-day anoxic incubation (Figure 1a). This demonstrated the occurrence of Feammox in both uncultivated and paddy soils, as $\mathrm{N}_{2}$ directly from Feammox or Feammox-produced $\mathrm{NO}_{2}{ }^{-}$or $\mathrm{NO}_{3}{ }^{-}$followed by anammox or denitrification are the sole potential sources of ${ }^{30} \mathrm{~N}_{2}$ under anoxic conditions (Table 2). In the ${ }^{15} \mathrm{NH}_{4}{ }^{+}$treatment, the mean ${ }^{30} \mathrm{~N}_{2}$ production rates in

Table 2. Possible Processes for ${ }^{30} \mathrm{~N}_{2}$ and ${ }^{29} \mathrm{~N}_{2}$ Generation from ${ }^{15} \mathrm{NH}_{4}^{+}$under Anaerobic Conditions (after Yang et al., ${ }^{11}$ Modified $)^{a}$

\begin{tabular}{|c|c|c|c|}
\hline product & $\begin{array}{l}\text { nitrogen atom } \\
\text { source } 1\end{array}$ & $\begin{array}{l}\text { nitrogen atom } \\
\text { source } 2\end{array}$ & process \\
\hline \multirow[t]{3}{*}{${ }^{30} \mathrm{~N}_{2}$} & amended ${ }^{15} \mathrm{NH}_{4}^{+}$ & amended ${ }^{15} \mathrm{NH}_{4}^{+}$ & Feammox to $\mathrm{N}_{2}$ \\
\hline & amended ${ }^{15} \mathrm{NH}_{4}^{+}$ & ${ }^{15} \mathrm{NO}_{2}{ }^{-b}$ & Anammox \\
\hline & $\begin{array}{l}\text { Feammox-produced } \\
{ }^{15} \mathrm{NO}_{2}^{-} /{ }^{15} \mathrm{NO}_{3}^{-}\end{array}$ & $\begin{array}{l}\text { Feammox-produced } \\
{ }^{15} \mathrm{NO}_{2}^{-} /{ }^{15} \mathrm{NO}_{3}^{-}\end{array}$ & denitrification \\
\hline \multirow[t]{5}{*}{${ }^{29} \mathrm{~N}_{2}$} & amended ${ }^{15} \mathrm{NH}_{4}^{+}$ & indigenous ${ }^{14} \mathrm{NH}_{4}{ }^{+}$ & Feammox to $\mathrm{N}_{2}$ \\
\hline & amended ${ }^{15} \mathrm{NH}_{4}^{+}$ & indigenous ${ }^{14} \mathrm{NO}_{2}^{-}$ & Anammox \\
\hline & $\begin{array}{l}\text { Feammox-produced } \\
{ }^{15} \mathrm{NO}_{2}^{-}\end{array}$ & indigenous ${ }^{14} \mathrm{NH}_{4}{ }^{+}$ & Anammox \\
\hline & ${ }^{15} \mathrm{NO}_{2}^{-}-$Feammox-produced & $\begin{array}{l}\text { indigenous amino } \\
\text { compounds }\end{array}$ & codenitrification \\
\hline & $\begin{array}{l}\text { Feammox-produced } \\
{ }^{15} \mathrm{NO}_{2}^{-} /{ }^{15} \mathrm{NO}_{3}^{-}\end{array}$ & ${ }^{14} \mathrm{NO}_{2}^{-} /{ }^{14} \mathrm{NO}_{3}^{-}$ & denitrification \\
\hline \multicolumn{4}{|c|}{$\begin{array}{l}{ }^{a} \text { Indigenous }{ }^{14} \mathrm{NO}_{2}{ }^{-} /{ }^{14} \mathrm{NO}_{3}{ }^{-} \text {or Feammox-produced }{ }^{15} \mathrm{NO}_{2}{ }^{-} /{ }^{15} \mathrm{NO}_{3}{ }^{-} \\
\text {could be converted into }{ }^{14} \mathrm{NH}_{4}^{+} \text {or }{ }^{15} \mathrm{NH}_{4}^{+} \text {through dissimilatory } \\
\mathrm{NO}_{3}{ }^{-} \text {reduction to } \mathrm{NH}_{4}^{+} \text {, respectively. Therefore, no additional } \\
\text { processes for }{ }^{30} \mathrm{~N}_{2} \text { and }{ }^{29} \mathrm{~N}_{2} \text { generation from }{ }^{15} \mathrm{NH}_{4}^{+} \text {were established. } \\
{ }^{b} \text { Feammox can produce }{ }^{15} \mathrm{NO}_{2}{ }^{-} \text {or }{ }^{15} \mathrm{NO}_{3}{ }^{-} \text {from amended }{ }^{15} \mathrm{NH}_{4}^{+} \text {. }\end{array}$} \\
\hline
\end{tabular}

all paddy soils (i.e., RC11, RC12 and RC13 soils) varied from $0.17 \pm 0.01$ to $0.59 \pm 0.03 \mathrm{mg} \mathrm{N} \mathrm{kg} \mathrm{d}^{-1}$, which were significantly $(P<0.05)$ higher than that in the uncultivated soil $\left(0.04 \pm 0.01 \mathrm{mg} \mathrm{N} \mathrm{kg}^{-1} \mathrm{~d}^{-1}\right.$ for the RC10 soil) (Figure 1a). Furthermore, the presence of $\mathrm{C}_{2} \mathrm{H}_{2}$ caused a decrease (by 0.01-0.14 $\mathrm{mg} \mathrm{N} \mathrm{kg}^{-1} \mathrm{~d}^{-1}$, about 22-33\%; $P<0.05$ for all soils except RC10 soil) in the ${ }^{30} \mathrm{~N}_{2}$ production rates in all soils. Compared to the ${ }^{30} \mathrm{~N}_{2}$ formation, greater ${ }^{29} \mathrm{~N}_{2}\left({ }^{14} \mathrm{~N}^{15} \mathrm{~N}\right)$ formation was observed in all soils following the addition of ${ }^{15} \mathrm{NH}_{4}^{+}$and ${ }^{15} \mathrm{NH}_{4}^{+}+\mathrm{C}_{2} \mathrm{H}_{2}$ (Figure 1b). Within the chronosequence, the ${ }^{29} \mathrm{~N}_{2}$ production rates showed similar trends to those observed in the ${ }^{30} \mathrm{~N}_{2}$ production rates in the ${ }^{15} \mathrm{NH}_{4}{ }^{+}$or ${ }^{15} \mathrm{NH}_{4}^{+}+\mathrm{C}_{2} \mathrm{H}_{2}$ treatments.

In addition to ${ }^{15} \mathrm{~N}_{2}$ (i.e., ${ }^{30} \mathrm{~N}_{2}$ and ${ }^{29} \mathrm{~N}_{2}$ ), headspace ${ }^{15} \mathrm{~N}_{2} \mathrm{O}$ (i.e., ${ }^{46} \mathrm{~N}_{2} \mathrm{O}$ and $\left.{ }^{45} \mathrm{~N}_{2} \mathrm{O}\right)$ significantly $(P<0.05)$ accumulated only in the presence of $\mathrm{C}_{2} \mathrm{H}_{2}$ in all soils, and ${ }^{46} \mathrm{~N}_{2} \mathrm{O}$ accumulated to a lesser extent compared to the ${ }^{45} \mathrm{~N}_{2} \mathrm{O}$ (Figure $1 c, d)$. Moreover, for all soils, the extent of headspace ${ }^{46} \mathrm{~N}_{2} \mathrm{O}$ accumulation (by $0.01-0.10 \mathrm{mg} \mathrm{N} \mathrm{kg} \mathrm{m}^{-1} \mathrm{~d}^{-1}$ ) was slightly lower than the extent of decrease in ${ }^{30} \mathrm{~N}_{2}$ production (by $0.01-0.14$ mg $\mathrm{N} \mathrm{kg}^{-1} \mathrm{~d}^{-1}$ ) after $\mathrm{C}_{2} \mathrm{H}_{2}$ addition, probably resulting from the partial dissolution of ${ }^{46} \mathrm{~N}_{2} \mathrm{O}$ produced in the liquid phase. Within the chronosequence, the lowest headspace ${ }^{46} \mathrm{~N}_{2} \mathrm{O}$ and ${ }^{45} \mathrm{~N}_{2} \mathrm{O}$ production rates were observed in the uncultivated RC10 soil, while the highest were in the RC12 soil.

Iron Reduction during Anoxic Incubations. For all soils, the amount of ferrous iron (Fe(II)) was significantly increased in all treatments after the 6-day incubation, and the extent of increase in the ${ }^{15} \mathrm{NH}_{4}^{+}$and ${ }^{15} \mathrm{NH}_{4}^{+}+\mathrm{C}_{2} \mathrm{H}_{2}$ treatments was significantly $(P<0.05)$ greater than in the control (Figure 2$)$. Total extractable $\mathrm{Fe}$ in all treatments was fairly constant throughout the incubation (Figure 2). These results indicated
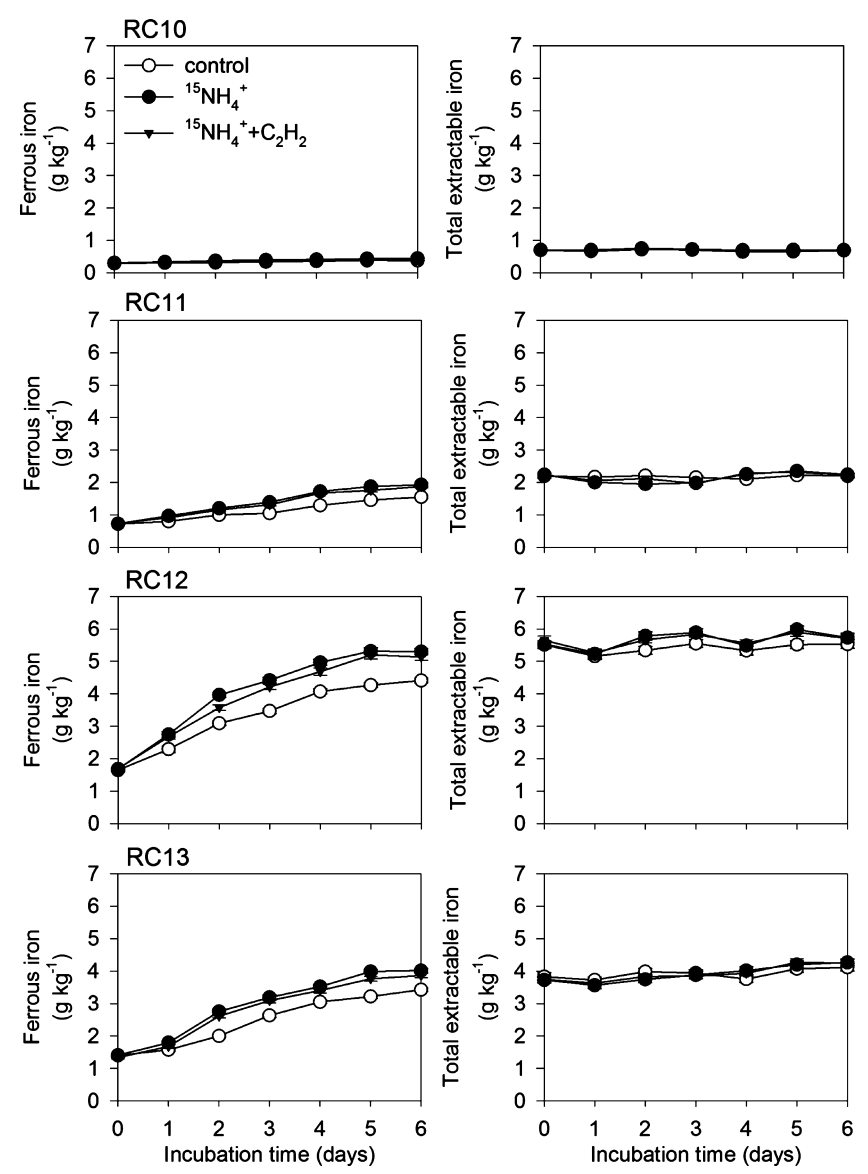

Figure 2. Kinetics of ferrous iron and total extractable iron during the anoxic incubation of slurries within the chronosequence. Error bars represent standard errors $(n=6)$.

that part of the soil indigenous microbially reducible $\mathrm{Fe}(\mathrm{III})$ was reduced to $\mathrm{Fe}(\mathrm{II})$, and ${ }^{15} \mathrm{NH}_{4}^{+}$addition promoted $\mathrm{Fe}(\mathrm{II})$ production. Moreover, in the ${ }^{15} \mathrm{NH}_{4}^{+}$and ${ }^{15} \mathrm{NH}_{4}^{+}+\mathrm{C}_{2} \mathrm{H}_{2}$ treatments, the extent of increase in $\mathrm{Fe}$ (II) concentration in the $\mathrm{RC} 10$ soil was $130 \pm 4.1-139 \pm 5.7 \mathrm{mg} \mathrm{kg}^{-1}$ (increased by approximately $44 \%$ ) after the incubations, which were considerably $(P<0.05)$ lower than in the other soils (1130 $\pm 22-3615 \pm 54 \mathrm{mg} \mathrm{kg}^{-1}$, by about $\left.151-215 \%\right)$.

Correlation Analysis of Iron Reduction and ${ }^{15} \mathrm{~N}_{2}$ Production Rates. Linear regression analysis was used to study the relationship between $\mathrm{Fe}(\mathrm{III})$ reduction and ${ }^{15} \mathrm{~N}_{2}$ (i.e., ${ }^{30} \mathrm{~N}_{2}$ and ${ }^{29} \mathrm{~N}_{2}$ ) production rates. For the chronosequence, $\mathrm{Fe}(\mathrm{III})$ reduction rate showed a significant and positive correlation with the ${ }^{30} \mathrm{~N}_{2}\left(R^{2}=0.878\right)$ and ${ }^{29} \mathrm{~N}_{2}\left(R^{2}=0.933\right)$ production rate, respectively, further indicating the occurrence of Feammox in both uncultivated and paddy soils (Figure 3).

Correlation Analysis of Rate Measurements and Soil Chemical Characteristics. Of all the soil chemical properties examined, the ${ }^{30} \mathrm{~N}_{2}$ production rates exhibited a strong correlation only with soil microbially reducible $\mathrm{Fe}(\mathrm{III})$ levels (Pearson correlation coefficient 0.967, $P<0.01$; SI Table S1). Likewise, the ${ }^{29} \mathrm{~N}_{2}$ production rates also showed a significant and positive correlation (Pearson correlation coefficient 0.987, $P<0.01$ ) with the levels of microbially reducible Fe(III). Both ${ }^{46} \mathrm{~N}_{2} \mathrm{O}$ and ${ }^{45} \mathrm{~N}_{2} \mathrm{O}$ production rates were positively correlated with $\mathrm{NO}_{x}^{-}(P<0.05)$ and microbially reducible $\mathrm{Fe}(\mathrm{III})(P<$ $0.01)$ concentrations. 

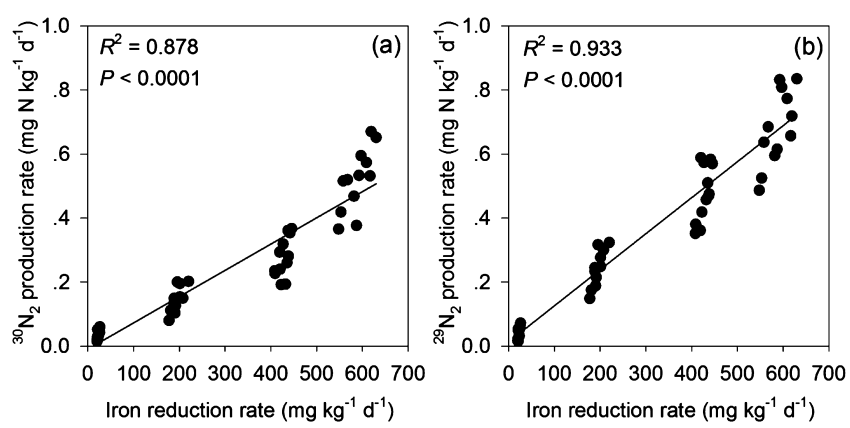

Figure 3. Relationships between iron reduction rate and ${ }^{30} \mathrm{~N}_{2}(\mathrm{a}),{ }^{29} \mathrm{~N}_{2}$ (b) production rate. Linear regression was used to test the correlation between the iron reduction and ${ }^{15} \mathrm{~N}_{2}$ production rates. Adjusted $R^{2}$ values with the associated $P$-values are shown.

\section{DISCUSSION}

Evidence for the Occurrence of Feammox in the Paddy Soil Chronosequence. Feammox is likely to occur in acidic paddy soils derived from quaternary red clay, which are rich in $\mathrm{Fe}$ (III) oxides and experience periodic anoxia. We thus estimated the potential for Feammox in such a paddy soil chronosequence with a gradient of microbially reducible $\mathrm{Fe}$ (III) levels through anoxic slurry incubations with ${ }^{15} \mathrm{NH}_{4}^{+}$tracer. Significant ${ }^{30} \mathrm{~N}_{2}$ production in the presence of ${ }^{15} \mathrm{NH}_{4}{ }^{+}$in all soils provides direct evidence for the occurrence of Feammox in the examined chronosequence (Figure 1a and Table 2). All soil slurries were preincubated anoxically to remove indigenous $\mathrm{O}_{2}$ and $\mathrm{NO}_{x}{ }^{-}$. The residual $\mathrm{NO}_{x}{ }^{-}$concentrations in all soil slurries after the preincubation were $0.72-1.6 \mathrm{mg} \mathrm{N} \mathrm{kg}{ }^{-1}$. This presence of $\mathrm{NO}_{x}{ }^{-}$may be resulted from indigenous $\mathrm{NO}_{3}{ }^{-}$and/ or $\mathrm{NO}_{2}^{-}$generation through Feammox. Strict anaerobic procedures were used throughout the experiment, and we believe that aerobic nitrification was negligible in this study (see $\mathrm{SI}$ ). Under these conditions, $\mathrm{N}_{2}$ directly from Feammox or Feammox-generated $\mathrm{NO}_{2}{ }^{-}$or $\mathrm{NO}_{3}{ }^{-}$followed by anammox or denitrification are the only potential pathways for ${ }^{30} \mathrm{~N}_{2}$ production (Table 2). All of these pathways, however, require the occurrence of Feammox at first. Codenitrification, which often co-occurs with denitrification and produces $\mathrm{N}_{2}$, ${ }^{23}$ can be ruled out as a potential source of ${ }^{30} \mathrm{~N}_{2}$ in this study, given that other ${ }^{15} \mathrm{~N}$-labeled nitrogen compounds including hydrazine and amino compounds, which could reduce Feammox-produced ${ }^{15} \mathrm{NO}_{2}{ }^{-}$to ${ }^{30} \mathrm{~N}_{2}$ were unavailable. ${ }^{9}$ Furthermore, the promotion of $\mathrm{Fe}$ (III) reduction after ${ }^{15} \mathrm{NH}_{4}^{+}$addition, together with the positive $(P<0.0001)$ correlation between $\mathrm{Fe}(\mathrm{III})$ reduction and ${ }^{30} \mathrm{~N}_{2}$ production rates, further provides strong evidence for the occurrence of Feammox in the chronosequence (Figures 2 and $3 \mathrm{a})$.

Potential Feammox rates are conservative estimates calculated from ${ }^{30} \mathrm{~N}_{2}$ production alone. ${ }^{11}$ The potential Feammox rates (i.e., ${ }^{30} \mathrm{~N}_{2}$ production rates) in all paddy soils ranged from 0.17 to $0.59 \mathrm{mg} \mathrm{N} \mathrm{kg} \mathrm{d}^{-1}$ (Figure 1a), which were comparable to that reported in tropical forest soils (about $0.32 \mathrm{mg} \mathrm{N} \mathrm{kg} \mathrm{d}^{-1}$ ) by Yang et al. ${ }^{11}$ Also, this order of magnitude was comparable to that of anammox ${ }^{1}$ and denitrification rates ${ }^{17}$ reported in paddy soils of China. Furthermore, the potential Feammox rates were found to be positively correlated with microbially reducible Fe(III) levels $(P$ $<0.01$; SI Table S1), indicating that soil microbially reducible $\mathrm{Fe}$ (III) level was a key factor controlling the Feammox activity, though microbially reducible $\mathrm{Fe}(\mathrm{III})$ is insoluble in soils with
$\mathrm{pH}>4 .{ }^{24}$ Various strategies, such as direct contact, have been proposed to be potentially used by microorganisms to access insoluble $\mathrm{Fe}$ (III) oxides and then facilitate $\mathrm{Fe}(\mathrm{III})$ reduction. ${ }^{25}$ Furthermore, it has been suggested that Feammox could be mediated by microorganisms, ${ }^{11}$ and different microbial populations might be involved in different Feammox pathways (i.e., produce $\mathrm{N}_{2}, \mathrm{NO}_{2}^{-}$or $\mathrm{NO}_{3}^{-}$via Feammox). We thus hypothesize that a higher microbially reducible Fe(III) level might provide more surface area for microbial contact, and thus potentially accelerate Feammox reaction, since the added ${ }^{15} \mathrm{NH}_{4}{ }^{+}$was sufficient enough to drive this reaction in all soils. Within the examined chronosequence, rice cultivation markedly enriches amorphous Fe(III) oxides. This presumably results from the enhancement of soil DOC after rice cultivation (Table 1), since that high concentrations of dissolved organic matter during flooding seasons could promote the release of structural $\mathrm{Fe}$ in clay minerals and support the formation of amorphous $\mathrm{Fe}(\mathrm{III})$ oxides. $^{15}$ High amorphous $\mathrm{Fe}(\mathrm{III})$ oxide concentrations and water-logged oxygen-limiting conditions under rice cultivation could promote Feammox reaction and thus potentially accelerate gaseous $\mathrm{N}$ loss.

It is noteworthy that, ${ }^{29} \mathrm{~N}_{2}$ also significantly accumulated in all soils amended with ${ }^{15} \mathrm{NH}_{4}^{+}$(Figure $1 \mathrm{~b}$ ), though the added ${ }^{15} \mathrm{NH}_{4}^{+}$pool (90 mg N kg${ }^{-1}$ ) was much larger than the indigenous ${ }^{14} \mathrm{NH}_{4}^{+}$pool in all soils $\left(7.0-21 \mathrm{mg} \mathrm{N} \mathrm{kg}^{-1}\right.$ after the preincubation), indicating that the indigenous ${ }^{14} \mathrm{NH}_{4}^{+}$and added ${ }^{15} \mathrm{NH}_{4}^{+}$pools were completely mixed. Several possible pathways exist for ${ }^{29} \mathrm{~N}_{2}$ production: the utilization of indigenous ${ }^{14} \mathrm{NH}_{4}^{+}$in combination with added ${ }^{15} \mathrm{NH}_{4}^{+}$in Feammox to $\mathrm{N}_{2}$, Feammox to $\mathrm{NO}_{2}^{-}$followed by anammox or codenitrification to $\mathrm{N}_{2}$, or Feammox to $\mathrm{NO}_{2}{ }^{-}$or $\mathrm{NO}_{3}{ }^{-}$ followed by denitrification to $\mathrm{N}_{2}$ (Table 2). Nevertheless, all of these pathways are based on anaerobic $\mathrm{NH}_{4}{ }^{+}$oxidation. As with the potential Feammox rates (i.e., ${ }^{30} \mathrm{~N}_{2}$ production rates), the ${ }^{29} \mathrm{~N}_{2}$ production rates were also positively correlated with $\mathrm{Fe}(\mathrm{III})$ reduction rates $(P<0.0001)$ and microbially reducible Fe(III) $(P<0.01)$ levels (Figure $3 \mathrm{~b}$ and SI Table S1), this further indicates that Feammox played an important part in anaerobic $\mathrm{NH}_{4}^{+}$oxidation, irrespective of the ultimate pathway for ${ }^{29} \mathrm{~N}_{2}$ production. Considering the generation of both ${ }^{30} \mathrm{~N}_{2}$ and ${ }^{29} \mathrm{~N}_{2}$, anaerobic $\mathrm{NH}_{4}{ }^{+}$oxidation consumed $0.40-0.60 \%$ and $2.1-9.1 \%$ of the added ${ }^{15} \mathrm{NH}_{4}^{+}$label in the uncultivated and paddy soils after the incubations, respectively.

Relative Contribution of Feammox Pathways. $\mathrm{N}_{2}$ directly from Feammox accounted for $67( \pm 2.4)$ to 78 $( \pm 4.5) \%$ of ${ }^{30} \mathrm{~N}_{2}$ loss in all soils treated with ${ }^{15} \mathrm{NH}_{4}{ }^{+}$alone, and there was no significant difference in this proportion among different soils. We used $\mathrm{C}_{2} \mathrm{H}_{2}$ to distinguish direct $\mathrm{N}_{2}$ generation via Feammox from gaseous $\mathrm{N}$ loss via anammox and/or denitrification of Feammox-produced $\mathrm{NO}_{2}{ }^{-}$and $\mathrm{NO}_{3}{ }^{-}$. $\mathrm{C}_{2} \mathrm{H}_{2}$ has been reported to not only block the reduction of $\mathrm{N}_{2} \mathrm{O}$ to $\mathrm{N}_{2}$, ${ }^{26}$ resulting in the accumulation of $\mathrm{N}_{2} \mathrm{O}$ produced from denitrification, but also could inhibit anammox ${ }^{27}$ and the first step of aerobic nitrification. ${ }^{28}$ In our study, aerobic nitrification was negligible (see SI), and the final concentration of $\mathrm{C}_{2} \mathrm{H}_{2}$ in the headspace was $30 \%(\mathrm{v} / \mathrm{v}$; about $11.5 \mathrm{mM})$, and therefore, well above the reported threshold for nearly complete inhibition of $\mathrm{N}_{2} \mathrm{O}$ reduction $(\geq 290 \mu \mathrm{M})^{26,27,29}$ and anammox $(\geq 30 \mu \mathrm{M}){ }^{27}$ Therefore, $\mathrm{N}_{2}$ directly from Feammox was thought to be the sole pathway of ${ }^{30} \mathrm{~N}_{2}$ production in the ${ }^{15} \mathrm{NH}_{4}{ }^{+}+\mathrm{C}_{2} \mathrm{H}_{2}$ treatment (Table 2). A decrease in ${ }^{30} \mathrm{~N}_{2}$ production caused by $\mathrm{C}_{2} \mathrm{H}_{2}$ addition in all soils indicating 
that about $22-33 \%$ of ${ }^{30} \mathrm{~N}_{2}$ loss in both uncultivated and paddy soils was ascribed to anammox and/or denitrification of Feammox-produced ${ }^{15} \mathrm{NO}_{2}{ }^{-}$and ${ }^{15} \mathrm{NO}_{3}{ }^{-}$, the remainder being due to $\mathrm{N}_{2}$ directly from Feammox. This suggests that direct $\mathrm{N}_{2}$ production is dominantly via Feammox in the chronosequence. Theoretically, $\mathrm{N}_{2}$ directly from Feammox is also energetically more favorable than Feammox to $\mathrm{NO}_{2}{ }^{-}$or $\mathrm{NO}_{3}{ }^{-}$and occurs under a wider range of conditions (e.g., a wider $\mathrm{pH}$ range). ${ }^{11}$

We also detected significant headspace ${ }^{46} \mathrm{~N}_{2} \mathrm{O}$ accumulation in all soils only in the presence of $\mathrm{C}_{2} \mathrm{H}_{2}$ (Figure 1c). $\mathrm{N}_{2} \mathrm{O}$ is produced in soils during various microbial processes, including aerobic nitrification, codenitrification, and denitrification. ${ }^{9,30}$ In our study, aerobic nitrification was negligible, and codenitrification is also excluded as a potential source of ${ }^{46} \mathrm{~N}_{2} \mathrm{O}$ since other ${ }^{15} \mathrm{~N}$-labeled nitrogen compounds which could reduce Feammox-produced ${ }^{15} \mathrm{NO}_{2}{ }^{-}$to ${ }^{46} \mathrm{~N}_{2} \mathrm{O}$, such as hydrazine and azide, were unavailable. ${ }^{9}$ Thus, the ${ }^{46} \mathrm{~N}_{2} \mathrm{O}$ accumulation in the headspace with $\mathrm{C}_{2} \mathrm{H}_{2}$ only came from the denitrification of Feammox-produced ${ }^{15} \mathrm{NO}_{2}{ }^{-}$and/or ${ }^{15} \mathrm{NO}_{3}{ }^{-}$. On the basis of the total production rates of ${ }^{46} \mathrm{~N}_{2} \mathrm{O}$ in the gas and liquid phases, approximately $0.01-0.14 \mathrm{mg} \mathrm{N} \mathrm{kg} \mathrm{d}^{-1}$ in all soils was oxidized to ${ }^{15} \mathrm{NO}_{2}^{-}$or ${ }^{15} \mathrm{NO}_{3}{ }^{-}$via Feammox at first and subsequently reduced to ${ }^{46} \mathrm{~N}_{2} \mathrm{O}$ via denitrification (see SI), occupying $19-28 \%$ of ${ }^{30} \mathrm{~N}_{2}$ loss in all soils. This proportion supported the result calculated from the difference in ${ }^{30} \mathrm{~N}_{2}$ production with and without $\mathrm{C}_{2} \mathrm{H}_{2}$.

Proportion of Iron Reduction Associated with Feammox. Interestingly, the molar ratio of measured ${ }^{30} \mathrm{~N}_{2}$ to $\mathrm{Fe}$ (II) production following the addition of ${ }^{15} \mathrm{NH}_{4}{ }^{+}$alone does not match the stoichiometry shown in eq 1 in any of the soils, probably because only a minor proportion of the $\mathrm{Fe}(\mathrm{III})$ reduced was linked to the $\mathrm{NH}_{4}^{+}$oxidation in the examined chronosequence. ${ }^{14}$ Therefore, we determined the proportion of $\mathrm{Fe}$ (III) reduction attributed to Feammox in the ${ }^{15} \mathrm{NH}_{4}{ }^{+}$ treatment in all soils using the theoretical ratio of 3-6 mol of $\mathrm{Fe}(\mathrm{III})$ reduced per mole of $\mathrm{NH}_{4}^{+}$oxidized according to the thermodynamic calculations (see SI). On the basis of this approach, only $2.0-4.0 \%$ and $0.81-2.2 \%$ of $\mathrm{Fe}$ (III) reduction is associated with Feammox in the uncultivated and paddy soils, respectively. It is assumed that the majority of Fe(III) reduced was potentially involved in the oxidation of soil organic matter, given that organic compounds are served as common electron donors for $\mathrm{Fe}$ (III) reduction under anaerobic conditions in addition to $\mathrm{NH}_{4}^{+}{ }^{+31}$ This assumption might explain why the highest proportion of $\mathrm{Fe}(\mathrm{III})$ reduction associated with Feammox was in the uncultivated soil $(2.0-4.0 \%)$, which has the lowest TOC content, while the lowest proportion was in the paddy soil $\mathrm{RC} 13(0.81-1.6 \%)$ with the highest TOC content (Table 1). Furthermore, the proportions of $\mathrm{Fe}(\mathrm{III})$ reduction associated with Feammox in the examined chronosequence were higher than previously reported (0.4$0.8 \%$ ) by Yang et al. ${ }^{11}$ This may also be related to the difference in soil TOC content, as the upland soils used in that study contained about $12 \%$ of organic carbon, ${ }^{32}$ whereas the chronosequence used in this study contained only $0.87-2.4 \%$ (Table 1). Therefore, it is suggestive to hypothesize that soils deficient in organic carbon might utilize $\mathrm{NH}_{4}{ }^{+}$as an electron donor more readily than those rich in organic carbon when $\mathrm{Fe}$ (III) oxide is served as sole electron acceptor. This is particularly important in the subtropical region of China, where soil fertility (such as organic carbon levels) is often very low while amorphous $\mathrm{Fe}$ (III) oxides are abundant, due to heavy weathering and nutrient leaching. ${ }^{33}$
Estimation of Ecosystem Ammonia Loss through Feammox. On the basis of rates obtained from slurry incubations and soil bulk density, it is estimated that the potential ammonia loss via Feammox $(0-10 \mathrm{~cm}$ depth) in all paddy soils was $7.8-61 \mathrm{~kg} \mathrm{~N} \mathrm{ha}^{-1}$ year $^{-1}$, accounting for approximately $3.9-31 \%$ of the $\mathrm{N}$ fertilizer usually applied to paddy soils in China (about $200 \mathrm{~kg} \mathrm{~N} \mathrm{ha}^{-1}$ year $^{-1}$ ), ${ }^{4,17}$ which was much greater than in the uncultivated soil $(2.1-8.6 \mathrm{~kg} \mathrm{~N}$ $\mathrm{ha}^{-1}$ year $^{-1} ; 1.0-4.3 \%$ ) (see SI), indicating that rice cultivation could facilitate more $\mathrm{N}$ loss via Feammox. The potential $\mathrm{N}$ loss via Feammox in the chronosequence is comparable to that reported for $\mathrm{NH}_{3}$ volatilization $(9-40 \%$ of the applied $\mathrm{N}$ fertilizer), leaching (3-9\%), runoff (5-7\%), denitrification (up to $40 \%$ ) and anammox (about 23\%) from paddy soils in China. ${ }^{1,3-5,17}$ This suggests that Feammox could potentially be an important pathway for $\mathrm{N}$ loss in paddy soils, and change our current estimates of total $\mathrm{N}$ losses from terrestrial ecosystems. However, the estimate of the environmental importance of Feammox process as an important pathway for $\mathrm{N}$ loss in paddy soils still appears to be linked with a uncertainty because slurry incubations in this study might overestimate the actual in situ activity due to the anoxic conditions and release of soil labile organic $\mathrm{C}$ via slurrying that stimulate $\mathrm{Fe}(\mathrm{III})$ reduction. Therefore, more studies that simulate the in situ conditions are needed to quantitatively determine the importance of Feammox as an alternative $\mathrm{N}$ loss pathway in paddy soils.

In summary, for the first time, we provide direct evidence for the occurrence of Feammox in paddy soils, and found that direct $\mathrm{N}_{2}$ production via Feammox is the dominant pathway of gaseous $\mathrm{N}$ loss. Furthermore, rice cultivation could progressively enrich indigenous microbially reducible $\mathrm{Fe}(\mathrm{III})$, therefore accelerating the Feammox reaction, resulting in more gaseous $\mathrm{N}$ loss. It is estimated that a total loss of 7.8$61 \mathrm{~kg} \mathrm{~N} \mathrm{ha}^{-1}$ year $^{-1}$ is linked to Feammox in paddy soils, accounting for about $3.9-31 \%$ of the $\mathrm{N}$ fertilizer usually applied to paddy soils in China. This study reveals that rice cultivation, in which a large portion of global synthesized $\mathrm{N}$ is used, could fuel $\mathrm{N}$ loss from soils via Feammox, and provides insights into alternative $\mathrm{N}$ loss from terrestrial ecosystems. This study demonstrates a poorly understood yet important process of $\mathrm{N}$ cycling, and warrants extensive investigation at different scales.

\section{ASSOCIATED CONTENT}

\section{Supporting Information}

Details on supportive methods and discussion; the sampling design and image of the examined paddy soil chronosequence; and the Pearson correlations between soil chemical characteristics and rate measurements within the chronosequence. This material is available free of charge via the Internet at http:// pubs.acs.org.

\section{AUTHOR INFORMATION}

\section{Corresponding Author}

*Phone: 86-592-6190997; fax: 86-592-6190997; e-mail: ygzhu@rcees.ac.cn.

\section{Notes}

The authors declare no competing financial interest.

\section{ACKNOWLEDGMENTS}

The authors would like to thank L. Molstad (UMB Nitrogen group, Norwegian University of Life Sciences) for providing software and constructing the robotized incubation system for 
analyzing gas kinetics. This study was financially supported by the National Natural Science Foundation of China (41090282 and 41090284) and the Strategic Priority Research Program of Chinese Academy of Sciences (XDB15020300 and XDB15020400).

\section{REFERENCES}

(1) Zhu, G.; Wang, S.; Wang, Y.; Wang, C.; Risgaard-Petersen, N.; Jetten, M.; Yin, C. Anaerobic ammonia oxidation in a fertilized paddy soil. ISME J. 2011, 5, 1905-1912.

(2) Cui, S.; Shi, Y.; Groffman, P. M.; Schlesinger, W. H.; Zhu, Y. G. Centennial-scale analysis of the creation and fate of reactive nitrogen in China (1910-2010). Proc. Natl. Acad. Sci. U.S.A. 2013, 110, 20522057.

(3) Xing, G. X.; Zhu, Z. L. An assessment of N loss from agricultural fields to the environment in China. Nutr. Cycl. Agroecosys. 2000, 57, $67-73$.

(4) Zhao, X.; Xie, Y. X.; Xiong, Z. Q.; Yan, X. Y.; Xing, G. X.; Zhu, Z. L. Nitrogen fate and environmental consequence in paddy soil under rice-wheat rotation in the Taihu lake region, China. Plant Soil 2009, $319,225-234$

(5) Zhu, J. G.; Han, Y.; Liu, G.; Zhang, Y. L.; Shao, X. H. Nitrogen in percolation water in paddy fields with a rice/wheat rotation. Nutr. Cycl. Agroecosys. 2000, 57, 75-82.

(6) Liang, X. Q.; Chen, Y. X.; Li, H.; Tian, G. M.; Ni, W. Z.; He, M. M.; Zhang, Z. J. Modeling transport and fate of nitrogen from urea applied to a near-trench paddy field. Environ. Pollut. 2007, 150, 313320.

(7) Li, H.; Liang, X. Q.; Chen, Y. X.; Tian, G. M.; Zhang, Z. J. Ammonia volatilization from urea in rice fields with zero drainage water management. Agric. Water Manage. 2008, 95, 887-894.

(8) Cavigelli, M. A.; Robertson, G. P. The functional significance of denitrifier community composition in a terrestrial ecosystem. Ecology 2000, 81, 1402-1414.

(9) Spott, O.; Russow, R; Stange, C. F. Formation of hybrid $\mathrm{N}_{2} \mathrm{O}$ and hybrid $\mathrm{N}_{2}$ due to codenitrification: First review of a barely considered process of microbially mediated N-nitrosation. Soil Biol. Biochem. 2011, 43, 1995-2011.

(10) Long, A.; Heitman, J.; Tobias, C.; Philips, R.; Song, B. Cooccurring anammox, denitrification, and codenitrification in agricultural soils. Appl. Environ. Microbiol. 2013, 79, 168-176.

(11) Yang, W. H.; Weber, K. A.; Silver, W. L. Nitrogen loss from soil through anaerobic ammonium oxidation coupled to iron reduction. Nat. Geosci. 2012, 5, 538-541.

(12) Clément, J. C.; Shrestha, J.; Ehrenfeld, J. G.; Jaffé, P. R. Ammonium oxidation coupled to dissimilatory reduction of iron under anaerobic conditions in wetland soils. Soil Biol. Biochem. 2005, 37, 2323-2328.

(13) Sawayama, S. Possibility of anoxic ferric ammonium oxidation. J. Biosci. Bioeng. 2006, 101, 70-72.

(14) Shrestha, J.; Rich, J. J.; Ehrenfeld, J. G.; Jaffé, P. R. Oxidation of ammonium to nitrite under iron-reducing conditions in wetland soils: Laboratory, field demonstrations, and push-pull rate determination. Soil Sci. 2009, 174, 156-164.

(15) Kögel-Knabner, I.; Amelung, W.; Cao, Z.; Fiedler, S.; Frenzel, P.; Jahn, R.; Kalbitz, K.; Kölbl, A.; Schloter, M. Biogeochemistry of paddy soils. Geoderma 2010, 157, 1-14.

(16) Han, G.; Zhang, G. Changes in magnetic properties and their pedogenetic implications for paddy soil chronosequences from different parent materials in south China. Eur. J. Soil Sci. 2013, 64, 435-444.

(17) Ju, X. T.; Xing, G. X.; Chen, X. P.; Zhang, S. L.; Zhang, L. J.; Liu, X. J.; Cui, Z. L.; Yin, B.; Christie, P.; Zhu, Z. L.; Zhang, F. S. Reducing environmental risk by improving $\mathrm{N}$ management in intensive Chinese agricultural systems. Proc. Natl. Acad. Sci. U.S.A. 2009, 106, 3041-3046.
(18) Li, S.; Deng, H.; Rensing, C.; Zhu, Y. G. Compaction stimulates denitrification in an urban park soil using ${ }^{15} \mathrm{~N}$ tracing technique. Environ. Sci. Pollut. Res. 2014, 21, 3783-3791.

(19) Molstad, L.; Dorsch, P.; Bakken, L. R. Robotized incubation system for monitoring gases $\left(\mathrm{O}_{2}, \mathrm{NO}, \mathrm{N}_{2} \mathrm{O}\right.$ and $\left.\mathrm{N}_{2}\right)$ in denitrifying cultures. J. Microbiol. Meth. 2007, 71, 202-211.

(20) Lewicka-Szczebak, D.; Well, R.; Giesemann, A.; Rohe, L.; Wolf, $\mathrm{U}$. An enhanced technique for automated determination of ${ }^{15} \mathrm{~N}$ signatures of $\mathrm{N}_{2},\left(\mathrm{~N}_{2}+\mathrm{N}_{2} \mathrm{O}\right)$ and $\mathrm{N}_{2} \mathrm{O}$ in gas samples. Rapid Commun. Mass Spectrom. 2013, 27, 1548-1558.

(21) Zhu, J.; Mulder, J.; Bakken, L.; Dörsch, P. The importance of denitrification for $\mathrm{N}_{2} \mathrm{O}$ emissions from an $\mathrm{N}$-saturated forest in SW China: Results from in situ ${ }^{15} \mathrm{~N}$ labeling experiments. Biogeochemistry 2013, 116, 103-117.

(22) Lovley, D. R; Phillips, E. J. P. Rapid assay for microbially reducible ferric iron in aquatic sediments. Appl. Environ. Microbiol. 1987, 53, 1536-1540.

(23) Kumon, Y.; Sasaki, Y.; Kato, I.; Takaya, N.; Shoun, H.; Beppu, T. Codenitrification and denitrification are dual metabolic pathways through which dinitrogen evolves from nitrate in Streptomyces antibioticus. J. Bacteriol. 2002, 184, 2963-2968.

(24) Weber, K. A.; Achenbach, L. A.; Coates, J. D. Microorganisms pumping iron: Anaerobic microbial iron oxidation and reduction. Nat. Rev. Micro. 2006, 4, 752-764.

(25) Nevin, K. P.; Lovley, D. R. Lack of production of electronshuttling compounds or solubilization of $\mathrm{Fe}(\mathrm{III})$ during reduction of insoluble $\mathrm{Fe}(\mathrm{III})$ oxide by Geobacter metallireducens. Appl. Environ. Microbiol. 2000, 66, 2248-2251.

(26) Sørensen, J. Denitrification rates in a marine sediments as measured by the acetylene inhibition technique. Appl. Environ. Microbiol. 1978, 36, 139-143.

(27) Jensen, M. M.; Thamdrup, B.; Dalsgaard, T. Effects of specific inhibitors on anammox and denitrification in marine sediments. Appl. Environ. Microbiol. 2007, 73, 3151-3158.

(28) Berg, P.; Klemedtsson, L.; Rosswall, T. Inhibitory effect of low partial pressures of acetylene on nitrification. Soil Biol. Biochem. 1982, 14, 301-303.

(29) Yoshinari, T.; Hynes, R.; Knowles, R. Acetylene inhibition of nitrous-oxide reduction and measurement of denitrification and nitrogen fixation in soil. Soil Biol. Biochem. 1977, 9, 177-183.

(30) Stevens, R. J.; Laughlin, R. J. Measurement of nitrous oxide and di-nitrogen emissions from agricultural soils. Nutr. Cycl. Agroecosyst. 1998, 52, 131-139.

(31) Lovley, D. R.; Phillips, E. J. P. Organic matter mineralization with reduction of ferric iron in anaerobic sediments. Appl. Environ. Microbiol. 1986, 51, 683-689.

(32) Teh, Y. A.; Dubinsky, E.; Silver, W.; Carlson, C. M. Suppression of methanogenesis by dissimilatory $\mathrm{Fe}(\mathrm{III})$-reducing bacteria in tropical rain forest soils: implications for ecosystem methane flux. Global Change Biol. 2008, 14, 413-422.

(33) Ahamadou, B.; Huang, Q.; Chen, W.; Wen, S.; Zhang, J.; Mohamed, I.; Cai, P.; Liang, W. Microcalorimetric assessment of microbial activity in long-term fertilization experimental soils of Southern China. FEMS Microbiol. Ecol. 2009, 70, 186-195. 